\title{
Choosing a Licensed Wood-Destroying Organism (WDO) Inspector ${ }^{1}$
}

Faith M. Oi, Paul Mitola and Kathleen Ruppert ${ }^{2}$

\section{The Problem}

During 2004, there were over 100 known illegal Termite and Wood-Destroying Organism (WDO) inspectors at work in the state, filling out Form 13645. Form 13645 is important to consumers in Florida because if an inspection for termites and other WDOs is done as part of a real estate transaction, then Form 13645 is required by Florida Statute 482.266. For more information on Form 13645, as it pertains to home buyers, see http://www.flaes.org/aes-ent/termitehelp/index.html and click on Understanding Real Estate WDO report Information. In addition, the home inspection industry remains unregulated.

\section{Types of Structural Inspections}

There are two types of inspections that a homeowner can request prior to the time of closing on real estate. The separation between these inspection types may not be apparent to someone new to the state or to inexperienced buyers. One type of inspection is for termites and other WDOs; the other is for the condition of the home. There are excellent home inspection companies in the state that will do a detailed report on the condition of the home, including notations of termite and other WDO damage on forms other than Form 13645. Our concern has been the home inspector crossing over to the pest control side and filling out Form 13645 without proper credentialing. Table 1 is a summary of the inspection differences.

\section{How do you know you are contracting the services of a legal termite inspector?}

1. Bottom line: The "licensee name" on Form 13645 (Figure 1, line 1) and the name on the check for payment of the fee (or other form of payment) should be consistent, otherwise you are dealing with an illegal operator.

Illegal operators have been identified by having the homeowner write a fee check to:

- Companies other than the pest control licensee

- The home inspection company they work for

1. This document is ENY-2005 (IN629), one of a series of the Department of Entomology and Nematology, Florida Cooperative Extension Service, Institute of Food and Agricultural Sciences, University of Florida. Date first published: July 2005. Please visit the EDIS Website at http://edis.ifas.ufl.edu.

2. Faith M. Oi, assistant extension scientist, Department of Entomology and Nematology; Paul Mitola, Environmental Specialist, DACS, Bureau of Entomology and Pest Control and Kathleen Ruppert, associate extension scientist, Program for Resource Efficient Sommunities, Cooperative Extension Service, Institute of Food and Agricultural Sciences, University of Florida, Gainesville, FL.

The Institute of Food and Agricultural Sciences (IFAS) is an Equal Opportunity Institution authorized to provide research, educational information and other services only to individuals and institutions that function with non-discrimination with respect to race, creed, color, religion, age, disability, sex, sexual orientation, marital status, national origin, political opinions or affiliations. U.S. Department of Agriculture, Cooperative Extension Service, University of Florida, IFAS, Florida A. \& M. University Cooperative Extension Program, and Boards of County Commissioners Cooperating. Larry Arrington, Dean 
Table 1. Comparison of the Scope of the Termite and WDO Inspection Versus a Typical Home Inspection in Regard to Regulation.

\begin{tabular}{|c|c|c|}
\hline & Termite and WDO Inspection & Home Inspection \\
\hline Purpose & $\begin{array}{l}\text { Report visible and accessible WDO and/or } \\
\text { damage. }\end{array}$ & $\begin{array}{l}\text { Determine structural soundness and } \\
\text { building code related issues. }\end{array}$ \\
\hline $\begin{array}{l}\text { Who can do the } \\
\text { inspection? }\end{array}$ & $\begin{array}{l}\text { Licensed pest control operators or their } \\
\text { employees with "WDO inspector" } \\
\text { endorsement on their ID card. }\end{array}$ & $\begin{array}{l}\text { Anyone. Home inspectors are not } \\
\text { regulated in the state of Florida. }\end{array}$ \\
\hline $\begin{array}{l}\text { Professional Liability } \\
\text { Insurance Required? }\end{array}$ & $\begin{array}{l}\text { Yes, for "errors and omissions." Company } \\
\text { must have a net worth over } \$ 100,000 \text { or } \\
\text { carry a minimum of } \$ 50,000 \text { insurance. } \\
\text { There are other insurance requirements as } \\
\text { well. }\end{array}$ & No. \\
\hline Regulated by: & $\begin{array}{l}\text { Florida State Statute } 482 \text { and Rule Chapter } \\
5 \mathrm{E}-14 \text { of Florida Administrative Code. }\end{array}$ & $\begin{array}{l}\text { None. Note that the } 2005 \text { Florida } \\
\text { Legislature attempted to regulate the } \\
\text { industry (HB 315), but the bill was } \\
\text { ultimately vetoed. }\end{array}$ \\
\hline
\end{tabular}

- Themselves for doing the inspection.

2. Be wary of who requests the inspection. These phrases may be evidence of an illegal operator. If the "requested by" information (Figure 1, line 4, Form 13645) contains wording such as:

- Requested by the Home Inspection Company" or

- Requested by the Home Inspection Company for homeowner," then be wary.

If you chose to go with one of these companies that use the above "requested by" designations and then you have a complaint, there is typically no contact information for the Florida Department of Agriculture and Consumer Services (FDACS) to follow up on. In other words, it will be hard to investigate.

\section{Are all inspectors with Home Inspection Companies illegal? No.}

There are some home inspection companies that have certified "WDO inspectors" working for them. Legitimate home inspection companies doing WDOs (Form 13645) will have an on-staff certified pest control operator in the FDACS Pest Control Operator category of termite. You can verify that you are dealing with a legal inspector by checking his/her ID card. The ID card should have the "WDO inspector" endorsement with the name of the pest control company on the card. Sometimes the home inspection company name and the pest control company name can be the same. Just remember, the check has to be written to the licensee on the WDO Form 13645.

\section{Are all inspectors with Pest Control Company IDs legal? No.}

There are some pest control companies "selling" ID cards with the "WDO inspector" endorsement on it. "Selling" an ID card is where a pest control operator provides ID cards for people he/she does not directly employ or supervise, which is illegal. Sometimes, these can be unlicensed home inspectors. If you are writing a check to someone other than the pest control company designated as licensee on the WDO Form 13645, then you are dealing with an illegal inspector.

\section{Other ways you can determine a legal termite and WDO inspector:}

- Ask to see the technicians ID card. It should have "State of Florida, Department of Agriculture and Consumer Services" printed at the top.

- Check the FDACS website to see if your inspector has a valid ID card at 


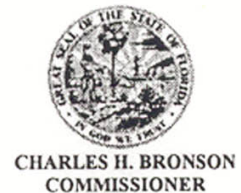

COMMISSIONER

Licensee name

Licensee address

Inspector

Requested by

Property Inspected

Specific structures inspected

Structures on property NOT inspected

Areas of structure(s) NOT inspected

Reason Not inspected

Florida Department of Agriculture \& Consumer Services

Division of Agricultural Environmental Services

WOOD-DESTROYING ORGANISMS INSPECTION REPORT

Section 482.226, Florida Statutes

Telephone: (850) 921-4177

License Number

Inspection Date Identification Card No.

Figure 1. First section of Form 13645, the Wood-Destroying Organisms Inspection Report.

http://www.safepesticideuse.com/Search/

PersonSearch.asp

- Verify that you are dealing with a licensed pest control company:

http://www.safepesticideuse.com/Search/

CompanySearch.asp

- Call the FDACS Bureau of Entomology and Pest Control at (850) 921-4177 if you have questions.

\section{How was this fraudulent practice uncovered?}

Real estate transactions typically require the completion of Form 13645, the Wood Destroying Organism Inspection Report. FDACS was alerted to the fraudulent practice after a buyer completed the transaction, moved in, and found several areas with WDO significant damage, not reported on the final inspection report. Since the purchase was complete, the buyer was left to either repair it at his cost or try and sue, another cost. As per procedure, FDACS investigated the complaint and uncovered the fraudulent WDO inspectors. Keep informed. Don't become a victim of illegal business practices.

\section{Additional Information}

For information pertaining to WDOs, see http://www.flaes.org/aes-ent/termitehelp/index.html. 